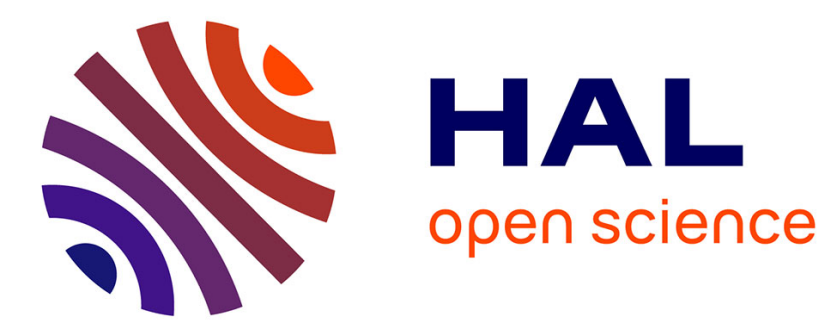

\title{
Modelling and prediction of deformation during sintering of a metal foam based SOFC (EVOLVE)
}

Meng Xu, David Masson, David Ryckelynck, Anthony Chesnaud, Alain Thorel

\section{To cite this version:}

Meng Xu, David Masson, David Ryckelynck, Anthony Chesnaud, Alain Thorel. Modelling and prediction of deformation during sintering of a metal foam based SOFC (EVOLVE). SOFC-XIV: Anodes 2, Jul 2015, Glasgow, United Kingdom. 10.1149/06801.2971ecst . hal-01199451

HAL Id: hal-01199451

https: / hal-mines-paristech.archives-ouvertes.fr/hal-01199451

Submitted on 15 Sep 2015

HAL is a multi-disciplinary open access archive for the deposit and dissemination of scientific research documents, whether they are published or not. The documents may come from teaching and research institutions in France or abroad, or from public or private research centers.
L'archive ouverte pluridisciplinaire HAL, est destinée au dépôt et à la diffusion de documents scientifiques de niveau recherche, publiés ou non, émanant des établissements d'enseignement et de recherche français ou étrangers, des laboratoires publics ou privés. 


\title{
Modelling and Prediction of Deformation During Sintering of a Metal Foam Based SOFC (EVOLVE)
}

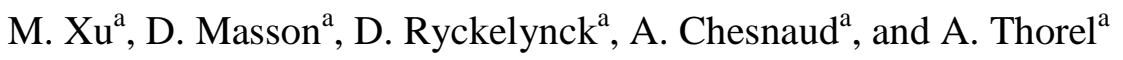 \\ ${ }^{a}$ Centre des Matériaux, Mines-ParisTech, PSL, UMR CNRS 7633, BP 87, 91003 Evry \\ Cedex, France
}

\begin{abstract}
Stacking of cells in a SOFC stack requires that each element be perfectly flat and deprived, as much as possible, of internal stresses while maintaining their electrochemical capabilities. The EVOLVE concept introduces a metal foam based anode in which the foam plays the role of current collector, gas diffuser and thermo-mechanical deformation buffer. Owing to the different mechanical behaviour of the anode components, the deformation during sintering cannot be intuitively anticipated. Therefore, the global deformation of the cell was modelled and simulated by Finite Element considering a phenomenological approach of the anisotropic sintering. The thermo-mechanical parameters of each component were determined experimentally by dilatometry and three-point bending tests operated under conditions identical to those of the sintering. Results provide relevant indications on components composition and morphology, and on the sintering conditions for producing flat and stackable cells.
\end{abstract}

\section{Introduction}

Solid Oxide Fuel Cell (SOFC) is one of the most attractive energy conversion system for stationary applications owing to its efficiency (80\% net in cogeneration) and fuel flexibility (hydrocarbons, $\mathrm{CO}$, bio-fuels,...). Although the feasibility and potentiality of SOFCs have already been demonstrated for ages, their repeated delaying large-scale commercialization still proves the existence of scientific and technological challenges which are imperative to solve. The main limitation of SOFCs that restrict their bringing to market remains the fast-acting deterioration of materials through redox cycling at the operating temperature, particularly on the anode side. In this day and age, three main configurations of planar SOFC have been experimented either at the laboratory or industrial scale. The electrolyte-supported cell (ESC) presents the advantage of being solid and adaptable despite its very low level of performances. Nowadays, the high power output of the anode-supported cell (ASC) makes this configuration the most mature design $(1,2)$, nevertheless its life span remains strongly limited owing to mechanical and chemical degradation mechanisms promoted at high temperature by the presence of nickel particles (3-7). Even if the operating temperature is reduced, coking and sulphur poisoning become the main source of performance degradation through redox cycles. The metal-supported cell (MSC) brings significant advantages in terms of mechanical stability and robustness under transient conditions (8), however its power density remains low compared to the ASC (9). 
The originality of the EVOLVE concept resides in the implementation of an innovative architectured current collector, on the anode side, based on materials that can withstand mechanical and chemical stresses. The current collector is constituted of a $\mathrm{NiCrAl}$ foam impregnated with $\mathrm{La}_{0.1} \mathrm{Sr}_{0.9} \mathrm{TiO}_{3+\delta}$ (LST), that also plays the role of gas diffuser as well as mechanical support (Figure 1) for the following sequence: the anode (LST or LST + GDC10), the electrolyte (YSZ), the diffusion barrier (GDC10) and the cathode (LSCF48). This configuration combines all attractive features of an ESC, i.e. the robustness and flexibility, with the advantage of an ASC, the electrical power supplied, along with the electrochemical stability under redox cycle of a MSC. Therefore, such architecture represents a strategy to improve performances, reliability and durability of SOFCs, along with their tolerance regarding sulphur.

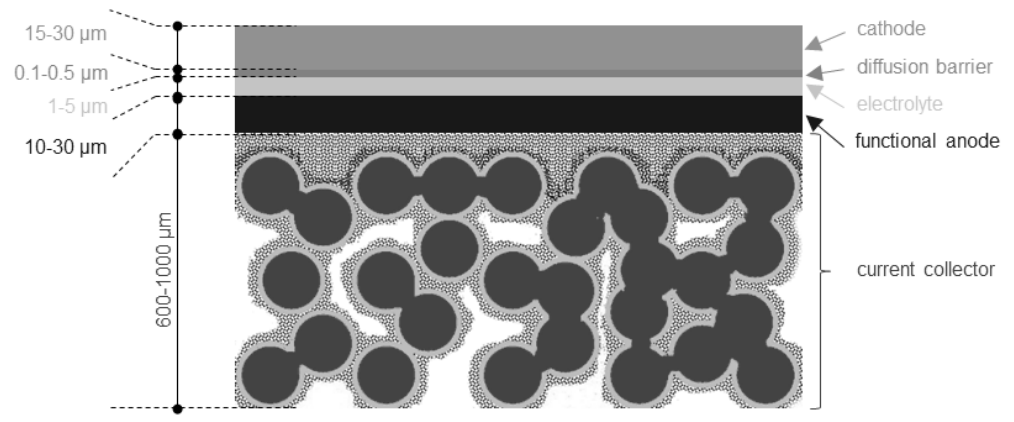

Figure 1. Schematic view of the layer configuration in the anode supported SOFC. The connected spheres represent the skeleton of the metal foam.

A predictive thermo-mechanical model that is able to describe the global deformation of this cell during sintering is proposed. The numerical simulation was carried out considering a phenomenological approach of the anisotropic sintering. This theoretical study aimed at reducing the "trials-error" experimental approach for optimizing the sintering cycle, guide the choice of materials and cell dimensions for producing flat and stackable cells.

\section{Experimental section}

\section{Fabrication of the anode-architectured cell}

A sequence of processes is implemented in order to fabricate a complete anodearchitectured cell. The current collector is made from a $\mathrm{NiCrAl}$ foam impregnated with a LST powder that is further cold rolled to decrease its thickness and porosity down to 500$600 \mu \mathrm{m}$ and $15 \%$ to $20 \%$, respectively. The $50 \mu \mathrm{m}$ LST (or GDC10-LST) functional anode is then deposited by screen printing or bar coating. Initial porosities of $45 \%$ are usually measured from SEM images recorded on microstructures of layers fabricated with such processes. The smooth surface of the anode is afterwards covered with a 15-20 $\mu \mathrm{m}$ thick YSZ electrolyte layer using an electron-beam physical vapor deposition technique achieved at $600{ }^{\circ} \mathrm{C}$. This latter is repeated for the coating of the $2-5 \mu \mathrm{m}$ thick GDC10 diffusion barrier. The advantage of this technic is that fully dense materials (relative density in the range 95-99\%) can be directly deposited at $600{ }^{\circ} \mathrm{C}$ without any additional post thermal treatment. The final LSCF48 cathode layer with a thickness varying from 30 to $50 \mu \mathrm{m}$ is then coated by screen printing; the initial layer porosity is 
about $45 \%$. At last, the whole multilayered structure is sintered at $1100{ }^{\circ} \mathrm{C}$ for 5 hours in air.

\section{$\underline{\text { Dilatometry tests }}$}

The anisotropic shrinkage curve for each component of the cell was deduced from dilatometry data of corresponding materials. The unidirectional variation of the dimension of samples, i.e. expansion and shrinkage, were successively recorded as a function of the temperature using a differential horizontal dilatometer DIL 402 CD from NETZSCH. This apparatus is equipped with two high resolution inductive sensors (digital resolution of $1.25 \mathrm{~nm}$ ) connected with an alumina pushrod that enables to apply continuously a pressure on the sample during measurement. Data collection was carried out in static air, between $35^{\circ} \mathrm{C}$ and $1570^{\circ} \mathrm{C}$ with a heating rate of $5^{\circ} \mathrm{C} \mathrm{min}{ }^{-1}$ while a static load of $1.59 \times 10^{-2} \mathrm{MPa}$ (45 $\mathrm{cN}$ applied on a surface of $28.3 \mathrm{~mm}^{2}$ ) was continuously applied. The thermal expansion of the sample holder was systematically subtracted from the raw data applying the DIN 51045-1 calibration correction and using alumina calibration standards. The data were recorded and analysed using the Netzsch-Proteus ${ }^{\circledR}$ software (v 6.1.0).

\section{Three-point bending tests}

The three-point bending tests were carried out in static air using a vertical multi-units SETARAM TMA-92 thermo-mechanical analyser equipped with a dedicated sample holder constituted of a flange supporting two alumina triangle-shaped edges spaced $8 \mathrm{~mm}$. A constant load of $45 \mathrm{cN}$ is continuously applied during measurement by means of an ended-edge supporting shaft having a knife-shaped section. The alumina shaft is connected to a linear variable differential transducer (LVDT) which records the vertical deflection of the middle line of the specimen. The displacement range was fixed to \pm 2.0 $\mathrm{mm}$ with a linearity of $0.3 \%$ and the vertical deflexion was measured with a resolution of $0.1 \mu \mathrm{m}$. Beam-shaped samples of $10 \mathrm{~mm}$ long by $3 \mathrm{~mm}$ wide by $500 \mu \mathrm{m}$ thick were used to neglect shear stresses. Vertical deflexion data were collected between $35^{\circ} \mathrm{C}$ and $1570^{\circ} \mathrm{C}$ with a heating rate of $5^{\circ} \mathrm{C} \mathrm{min}^{-1}$ and the maximal temperature was maintained for 5 hours. The data were collected and processed using the CALISTO v 1.076 software.

\section{Model and Numerical Simulation}

\section{Modelling of the deformation}

In order to predict the deformation of the cell during heating, a phenomenological approach of the sintering was considered. The procedure consists in following the total deformation of the cell over time during the heat treatment. This deformation occurs according to four successive processes: two reversible phenomena, i.e. (i) the elastic deformation $\left(\varepsilon^{\mathrm{e}}\right)$ and (ii) the thermal dilatation $\left(\varepsilon^{\text {th }}\right)$, followed by two simultaneous phenomena, i.e. (iii) a viscoplastic deformation $\left(\varepsilon^{\mathrm{vp}}\right)$ related to the creep and (iv) a shrinkage $\left(\varepsilon^{\mathrm{s}}\right)$ associated to sintering. The global behaviour law of the deformation kinetic can be expressed by:

$$
\underline{\dot{\varepsilon}}_{\text {total }}=\underline{\dot{\varepsilon}}^{\mathrm{e}}+\underline{\dot{\varepsilon}}^{\text {th }}+\underline{\dot{\varepsilon}}^{\mathrm{vp}}+\underline{\dot{\varepsilon}}^{\mathrm{s}}
$$


The viscoplastic deformation is driven by a thermally activated creep deformation Norton's law; the sintering shrinkage, also a thermally activated process, expresses the densification of the material. Elastic and thermal deformations were not taken into accounts as they contribute by an insignificant margin compared with irreversible $\left(\varepsilon^{\mathrm{vp}}\right.$ and $\varepsilon^{\mathrm{s}}$ ) processes. The model integrates morphological (initial $\mathrm{f}_{\mathrm{o}}$ and final $\mathrm{f}^{\infty}$ porosities) and mechanical characteristics of each constituent layer, as well as the cell dimensions (Figure 2a). In the present case, the improvement of the model application was achieved by considering the real mechanical behaviour of each material that was deduced from dilatometric and creep tests. These latter were operated in the same heat and atmosphere conditions as the real sintering. In addition, the anisotropic sintering was considered and detailed hereinbelow. For the modelling, the thickness of each layer of the cell was fixed (Table I), while cell diameters of $10 \mathrm{~mm}, 20 \mathrm{~mm}$, and $40 \mathrm{~mm}$ were implemented. The numerical simulation was carried out integrating the functional anode material either as single phase or composite (Table I).

TABLE I. Thickness of each layer implemented in the thermo-mechanical model.

\begin{tabular}{lccc}
\hline \multicolumn{1}{c}{ Designation } & Composition & Initial thickness & Initial porosity \\
\hline Current collector & NiCrAl-LST & $600 \mu \mathrm{m}$ & $15 \%$ \\
Anode & LST (or LST-GDC10) & $50 \mu \mathrm{m}$ & $45 \%$ \\
Electrolyte & YSZ & $15 \mu \mathrm{m}$ & $1 \%$ \\
Diffusion barrier & GDC10 & $2 \mu \mathrm{m}$ & $1 \%$ \\
Cathode & LSCF48 & $30 \mu \mathrm{m}$ & $45 \%$ \\
Cell & - & $\mathrm{t}_{\text {cell }}=697 \mu \mathrm{m}$ & - \\
\hline
\end{tabular}

For symmetry reasons, only a section of the cell was meshed ; a quadratic element (c2d8) without model reduction was used and applied to the cell element of diameter $\emptyset_{\text {cell }} / 2$ (Figure $2 \mathrm{a}$ and $\mathrm{b}$ ). The meshing was refined close to the layer interfaces. The numerical simulations were performed in $2 \mathrm{D}$ using the $\mathrm{Z}$-set finite element code, implemented in the "Zebulon" software and developed by MINES-ParisTech (10).

(a)

(b)

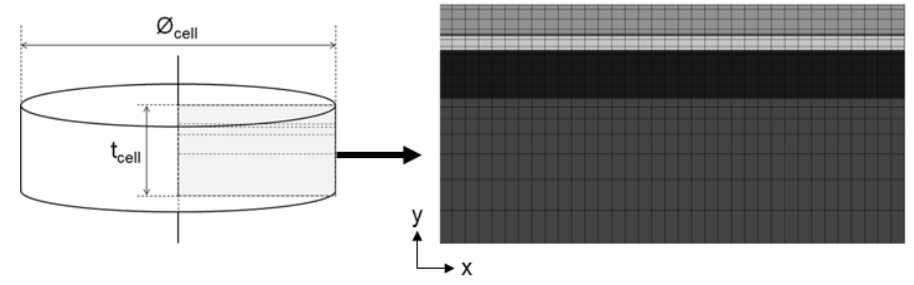

Figure 2. (a) Longitudinal section of a 2D-asymmetrical element extracted from the cylindrical cell and (b) its corresponding meshing. One layer corresponds to one grey level.

For the calculations, only the horizontal displacement $\left(\mathrm{U}_{1}\right)$ of the nodes on the left side of the cell element was blocked as if the cell was subjected to "free sintering". The initial porosity of each constituting layer of the cell (Table I) was set so that it is similar to that obtained by the corresponding shaping process. However, the "realistic condition" of sintering should be that one blocking the creep of the cell put on a substrate. 


\section{Modelling of the anisotropic shrinkage during sintering}

Experimentally, the samples for dilatometry tests are cylindrical with a diameter of 6 $\mathrm{mm}$. Given that pressure and temperature fields imposed to the samples are uniformly distributed on their surface, the mesh geometry and dimension will not impact results obtained from the simulation. As a matter of fact, the numerical geometry of the samples can be simplified using a 3D meshing of a linear cubic element (Figure 3a). For the calculation, the three displacements $\mathrm{U}_{1}$ (along $\mathrm{x}$ ), $\mathrm{U}_{2}$ (along $\mathrm{y}$ ) and $\mathrm{U}_{3}$ (along $\mathrm{z}$ ) of the $(0,0,0)$ origin point were blocked. In addition, the displacement $U_{3}$ of the $(0,0,1)$ point was blocked in order to avoid rotation of the element.
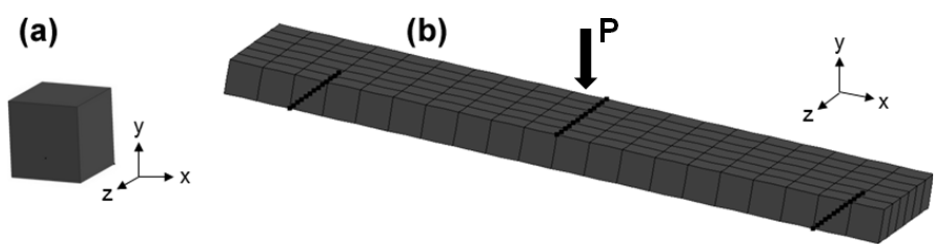

Figure 3. Geometrical elements used to model (a) the technical shrinkage and (b) the 3point bending tests.

An anisotropy model of the sintering was considered to simulate the material behaviour (11). The deformation kinetic of sintering depends on temperature and porosity of the sample. It can be expressed by a two-order tensor:

$$
\underline{\varepsilon}^{\mathrm{s}}(\mathrm{f}, \mathrm{T})=\left(\begin{array}{ccc}
\varepsilon_{\mathrm{x}}^{\mathrm{s}}(\mathrm{f}, \mathrm{T}) & 0 & 0 \\
0 & \varepsilon_{\mathrm{y}}^{\mathrm{s}}(\mathrm{f}, \mathrm{T}) & 0 \\
0 & 0 & \varepsilon_{\mathrm{z}}^{\mathrm{s}}(\mathrm{f}, \mathrm{T})
\end{array}\right)
$$

The sintering being thermally activated, the kinetic deformation of sintering in each direction can be written:

$$
\varepsilon_{\mathrm{x}, \mathrm{y}, \mathrm{z}}^{\mathrm{s}}(\mathrm{f}, \mathrm{T})=-\mathrm{A}_{\mathrm{o}} \times\left(\mathrm{f}-\mathrm{f}^{\infty}\right)^{\beta} \times \exp \left(-\frac{\mathrm{Q}_{\mathrm{s}}}{\mathrm{RT}}\right)
$$

$\mathrm{A}_{\mathrm{o}}$ is the pre-exponential factor, $\mathrm{f}$ and $\mathrm{f}^{\infty}$ the time-dependent and final porosities, respectively, $\beta$ a constant that depends on the material, $Q_{s}$ the sintering activation energy, and $\mathrm{R}$ the ideal gas constant. By introducing anisotropy coefficients for the sintering to describe the component of the deformation in the direction perpendicular to the cylinder axis, i.e. $\mathrm{y}$, the kinetic of deformation along $\mathrm{x}$ and $\mathrm{z}$ can be expressed as a function of $\varepsilon_{\mathrm{y}}^{\mathrm{s}}(\mathrm{f}, \mathrm{T})$ and $\mathrm{K}_{1}$ and $\mathrm{K}_{2}$ respectively:

$$
\begin{aligned}
& \varepsilon_{\mathrm{x}}^{\mathrm{s}}(\mathrm{f}, \mathrm{T})=\mathrm{K}_{1} \times \varepsilon_{\mathrm{y}}^{\mathrm{s}}(\mathrm{f}, \mathrm{T}) \\
& \varepsilon_{\mathrm{z}}^{\mathrm{s}}(\mathrm{f}, \mathrm{T})=\mathrm{K}_{2} \times \varepsilon_{\mathrm{y}}^{\mathrm{s}}(\mathrm{f}, \mathrm{T})
\end{aligned}
$$

with $\mathrm{K}_{1}=\mathrm{K}_{2}$ in the case of a cylinder-shaped sample. 


\section{Modelling of the 3-point bending tests}

In order to simulate the vertical deflexion of the rod-shaped samples submitted to 3point bending tests that will lead to the identification of creep kinetic parameters, a 3D meshing as illustrated in Figure $3 \mathrm{~b}$ was used. Since a force of $45 \mathrm{cN}$ is uniformly applied on a rectangular surface ( $3 \mathrm{~mm}$ length and $2 \mathrm{~mm}$ width) of the top surface of the element, the charge can be converted to a uniform pressure fields. For the calculation, the displacements $U_{1}$ and $U_{2}$ of the bottom left segment as well as the displacement $U_{2}$ of the right bottom segment of the $3 \mathrm{D}$ element were blocked. Besides, the $\mathrm{U}_{3}$ displacement of the $(0,0,0)$ origin was blocked. The viscous flowing is supposed to be linearly dependent of the stress in accordance with a creep associated with a high temperature diffusion process. Nevertheless, the kinetic of deformation also depends on the material porosity. So the kinetic of creep deformation is written as:

$$
\varepsilon_{\mathrm{vp}}^{\mathrm{s}}(\mathrm{f}, \mathrm{T})=\frac{1}{\eta(\mathrm{t}, \mathrm{T})} \times \underline{\underline{M}}(\mathrm{f}): \sigma
$$

Where $\eta(t, T)$ represents the viscosity of the material according to the Arrhenius law:

$$
\eta(t, T)=\frac{1}{\left(1-f_{o}\right) \times K_{o}} \times \exp \left(+\frac{Q_{v p}}{R T}\right)
$$

$\mathrm{Q}_{\mathrm{c}}$ is the creep activation energy, $\mathrm{R}$ the ideal gas constant and $\mathrm{T}$ the temperature. The tensor $\underline{\underline{M}}(\mathrm{f})$ of order 4 was introduced to model the effects of the porosity on the kinetic of deformation. The creep is assumed to be isotropic, therefore $\underline{\underline{\mathrm{M}}}(\mathrm{f})$ can be written:

$$
\underline{\underline{M}}(\mathrm{f})=\frac{3}{2} \times \mathrm{C}(\mathrm{f}) \times \underset{=}{\mathrm{J}}+\mathrm{F}(\mathrm{f}) \times \underline{\underline{I}}
$$

With $C(f)$ and $F(f)$ two coefficients that depend on the porosity defined as:

$$
\begin{aligned}
& C(f)=1+C_{o} \times f^{n_{c}} \\
& F(f)=F_{o} \times f^{n_{F}}
\end{aligned}
$$

Otherwise, the tensors of order 4, i.e. I and $\underset{\underline{J}}{\mathbf{J}}$ are expressed by:

$$
\begin{aligned}
& \mathrm{I}: \underline{\sigma}=\operatorname{tr}(\underline{\sigma}) \times \underline{\mathrm{I}} \\
& \underset{\mathrm{J}}{\mathrm{J}}: \underline{\sigma}=\underline{\sigma}-\frac{1}{3} \operatorname{tr}(\underline{\sigma}) \times \underline{\mathrm{I}}
\end{aligned}
$$

For NiCrAl foam, only the creep phenomenon occurs so that its deformation during sintering can be described according to a "Norton-Hoff" viscoplastic model given by: 


$$
\underline{\varepsilon}^{\mathrm{vp}}(\mathrm{f}, \mathrm{T})=\left\langle\frac{\underline{\sigma}}{\mathrm{K}(\mathrm{T})}\right\rangle_{+}^{\mathrm{n}}=\mathrm{k}_{\mathrm{o}} \times \exp \left(-\frac{\mathrm{Q}_{\mathrm{vp}}}{\mathrm{RT}}\right) \times\langle\underline{\sigma}\rangle_{+}^{\mathrm{n}}
$$

The creep activation energy $Q_{v p}$ is the same as the sintering activation energy $Q_{s}$ assuming that both phenomena are controlled by self-diffusion.

\section{Results and Discussion}

\section{Dilatometric measurements and modelling}

The longitudinal shrinkage $\left(\varepsilon_{1}\right)$ of all materials constituting the cell was measured on compacted powders, in the form of cylinder, as a function of the temperature. Tests were carried out in static air under a load of $45 \mathrm{cN}$. The result is displayed in Figure 4a for the YSZ electrolyte material. In the low temperature region $\left(<1000{ }^{\circ} \mathrm{C}\right)$, the compacted powder expands which results in an increase of the sample length. From $1000{ }^{\circ} \mathrm{C}$, the sintering takes place and the sample drastically shrinks up to $1400{ }^{\circ} \mathrm{C}$ and then its dimensions remain unchanged. During cooling, the contraction makes possible the determination of the thermal expansion coefficient (TEC) of the sample.

The technical curve was built by extracting the reversible thermal deformation $\varepsilon^{\text {th }}$ (equation 14) from the dilatometric data $\varepsilon_{\text {dil }}$. The resultant curve (Figure 4a) obtained is only comprised of the irreversible processes, i.e. the sintering and viscoplastic deformations that occur almost simultaneously. The sample length is reduced by $24 \%$ as illustrated by the evolution of the shrinkage curve recorded between room temperature (RT) and $1570{ }^{\circ} \mathrm{C}$. The shrinkage curve shows that the sample length does not evolve from RT to $600{ }^{\circ} \mathrm{C}$.

$$
\varepsilon_{\text {tech }}(\mathrm{t}, \mathrm{T})=\varepsilon_{\text {dil }}(\mathrm{t}, \mathrm{T})-\mathrm{TEC} \times 100 \times\left(\mathrm{T}-\mathrm{T}_{\mathrm{i}}\right)
$$

$\mathrm{T}_{\mathrm{i}}\left(=35^{\circ} \mathrm{C}\right)$ is the temperature from which dilatometric data were recorded. $\varepsilon_{\text {tech }}$ and $\varepsilon_{\mathrm{dil}}$ are the technical and dilatometric shrinkages, respectively.
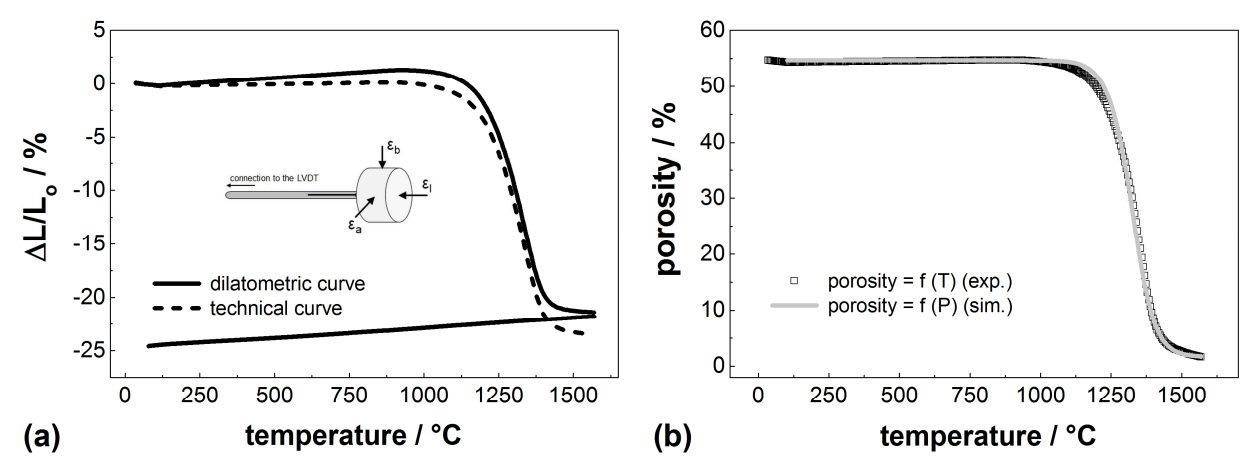

Figure 4. (a) Dilatometric (unbroken line) and technical shrinkage (dashed line) curves; the inset represents the measurement configuration in the sample-holder of the dilatometer; (b) evolution of the experimental (open squares) and simulated (light grey unbroken line) porosity of the YSZ material as a function of the temperature. 
TEC is the thermal expansion coefficient deduced from the slope of the linear portion of the dilatometric curve (Figure 4a) recorded during the cooling step. The evolution of the material porosity as a function of the temperature, displayed in Figure $4 \mathrm{~b}$, was then calculated using the theoretical approach reported by K. Maca et al. (12). The mechanical parameters $A_{o}, \beta$ and $Q_{s}$ of the sintering behaviour law were refined for each material by fitting the experimental curve displaying the porosity as a function of the temperature. In order to do this, all parameters were adjusted until both the simulated and experimental curves match. Figure $4 \mathrm{~b}$ illustrates an example of such a refinement achieved on the YSZ electrolyte material and leading to a perfect agreement between experimental and simulated curves. The morphological parameters $f_{o}$ and $f^{\infty}$ are data measured on the sample before and after sintering, respectively, and anisotropy factors $\left(K_{1}=K_{2}\right)$ are deduced from the total shrinkage $\varepsilon_{1}$ (inset in Figure 4a) along the cylinder axis. The same procedure was followed for the other materials. The experimental and simulated curves are compared in Figure 5a and refined parameters are gathered in Table II.
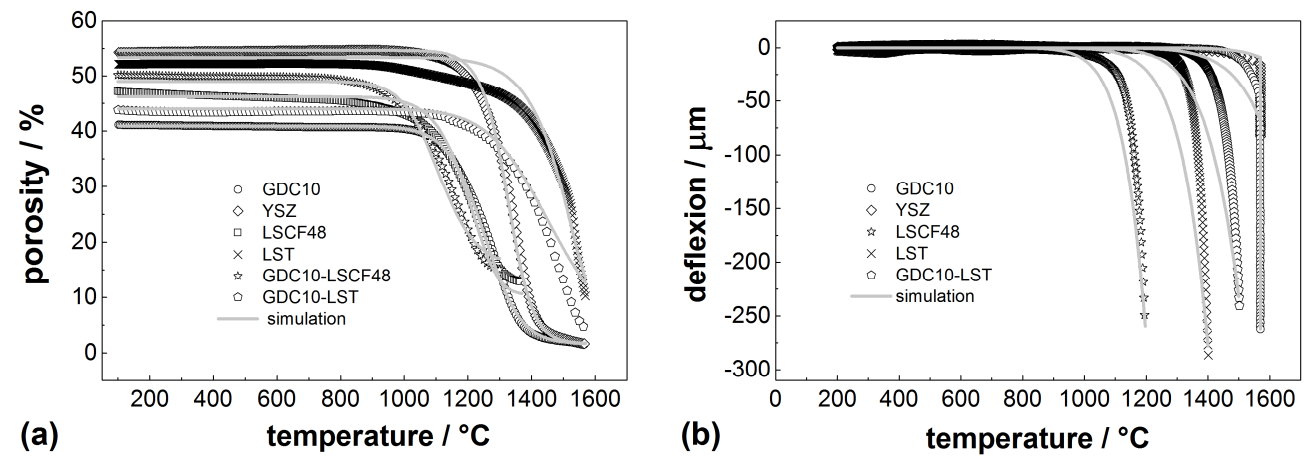

Figure 5. Evolution of (a) the porosity and (b) the deflexion of the sample versus the temperature. Symbols and unbroken light grey lines are used for experimental data and simulation, respectively.

Apart from materials containing the LST phase, a very good agreement between experimental and simulated data is noticed. Indeed, L. Amaral et al. reported a two-step densification process in nonstoichiometric LST ceramics (13).

TABLE II. Refined mechanical parameters and final porosities for all materials of the anode-architectured cell.

\begin{tabular}{lccccccc}
\hline Parameters & GDC10 & YSZ & LSCF48 & LST & $\begin{array}{c}\text { GDC10- } \\
\text { LSCF48 }\end{array}$ & $\begin{array}{c}\text { GDC10- } \\
\text { LST }\end{array}$ & NiCrAl \\
\hline $\mathrm{A}_{\mathrm{o}} / \mathrm{s}^{-1}$ & $8.25 \times 10^{5}$ & $1.43 \times 10^{9}$ & $5.12 \times 10^{4}$ & $4.50 \times 10^{3}$ & $5.32 \times 10^{5}$ & $1.29 \times 10^{3}$ & - \\
$\mathrm{K}_{\mathrm{o}}$ & 12.1 & $2.11 \times 10^{3}$ & 208 & 54.1 & $2.08 \times 10^{5}$ & 81.5 & - \\
$\beta$ & 1.55 & 1.64 & 1.18 & 0.70 & 1.93 & 2.00 & - \\
$\mathrm{f}^{\infty} / \%$ & 1.20 & 1.60 & 10.4 & 9.50 & 15.0 & 4.40 & - \\
$\mathrm{K}_{1}\left(=\mathrm{K}_{2}\right)$ & 0.940 & 0.948 & 0.985 & 0.567 & 0.937 & 0.951 & - \\
$\alpha_{\mathrm{exp}} / \times 10^{6} \mathrm{~K}^{-1}$ & 12.8 & 12.7 & 16.5 & 14.4 & 14.3 & 13.8 & 14.9 \\
$\eta_{\mathrm{o}} / \mathrm{MPa} . \mathrm{s}^{-1}$ & $8.26 \times 10^{-2}$ & $4.74 \times 10^{-4}$ & $4.81 \times 10^{-3}$ & $1.85 \times 10^{-2}$ & $4.81 \times 10^{-6}$ & $1.23 \times 10^{-2}$ & - \\
$\mathrm{Q} / \mathrm{kJ} \mathrm{mol}{ }^{-1}$ & 264 & 370 & 225 & 240 & 225 & 202 & 30 \\
$\mathrm{C}_{\mathrm{o}}$ & 1.50 & 1.50 & 1.10 & 1.50 & 1.10 & 1.50 & - \\
$\mathrm{n}_{\mathrm{c}}$ & 1.60 & 1.20 & 1.80 & 1.20 & 1.80 & 1.20 & - \\
$\mathrm{F}_{\mathrm{o}}$ & 1.00 & 1.00 & 1.00 & 1.00 & 1.00 & 1.00 & - \\
\hline
\end{tabular}




\section{Three-point bending tests and modelling}

The deflexion of each sample under constant load of $45 \mathrm{cN}$ was measured as a function of the temperature (Figure 5b) As with dilatometric measurements, dilatation effects were first removed from the raw data prior to numerical simulation.

\section{Modelling of deformation in complete cells}

The influence of the sintering temperature was investigated on laboratory-scale cells with $\emptyset_{\text {cell }}=10 \mathrm{~mm}$. Layer thicknesses as indicated in Table I were implemented in the model. An initial porosity of $15 \%$ was set for the NiCrAl-LST current collector. Three calculations were carried out in order to simulate deformation in the cell after sintering at $1100{ }^{\circ} \mathrm{C}, 1200{ }^{\circ} \mathrm{C}$ and $1300{ }^{\circ} \mathrm{C}$ for 5 hours. For the simulations, a heating rate of $5{ }^{\circ} \mathrm{C}$ $\min ^{-1}$ was implemented. As illustrated in Figure 6, a sintering at either $1100{ }^{\circ} \mathrm{C}$ and $1200{ }^{\circ} \mathrm{C}$ has a limited influence on the cell deformation. At higher temperature, e.g. $1300{ }^{\circ} \mathrm{C}$ (Figure $6 \mathrm{c}$ ), the cell significantly bends as a direct consequence of the important shrinkage of the LSCF48 cathode material that reaches its optimal sintering temperature.

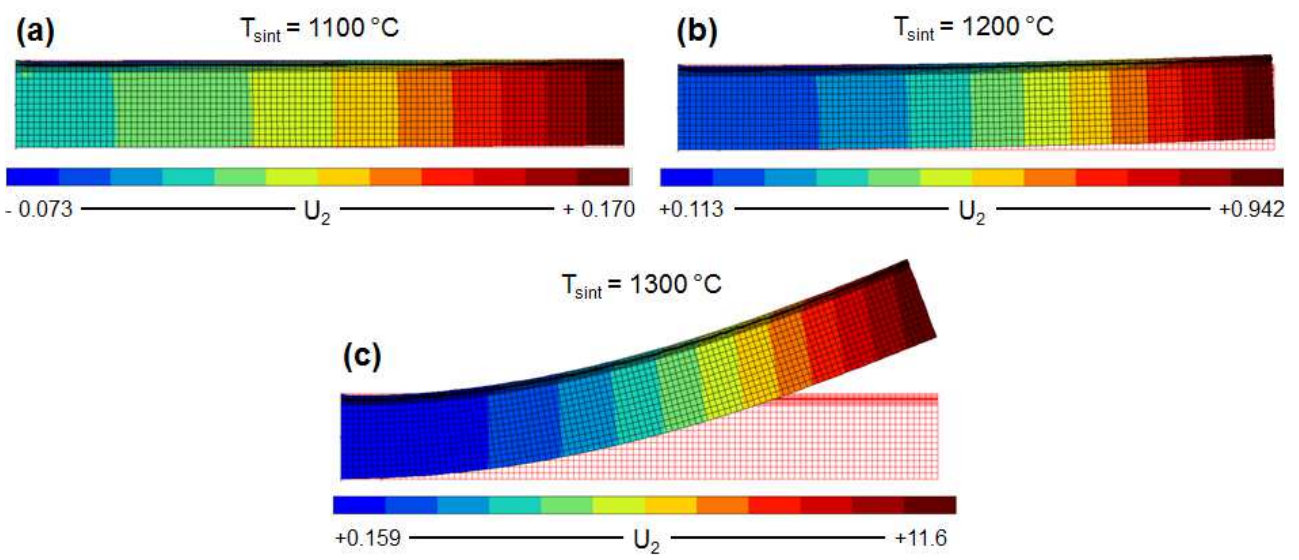

Figure 6. Finite element modelling of the curvature of the complete cell during sintering at (a) $1100{ }^{\circ} \mathrm{C}$, (b) $1200{ }^{\circ} \mathrm{C}$ and (c) $1300{ }^{\circ} \mathrm{C}$. The grid arrangement (in red) symbolizes the initial meshing of the cell.

In a second time, the influence of cell diameter on the total deformation was regarded. The calculations were carried out using initial thickness and porosities gathered in Table I and the sintering was operated at $1100{ }^{\circ} \mathrm{C}$ for 5 hours with a heating rate of $5{ }^{\circ} \mathrm{C} \mathrm{min}{ }^{-1}$. At such a sintering temperature, the Figure 7 shows that the cell diameter has an unimportant influence on the total deformation of the cell. Strong deformation will take place at a temperature from which the creep of materials becomes significant, that is to say $1200{ }^{\circ} \mathrm{C}$.

(a)

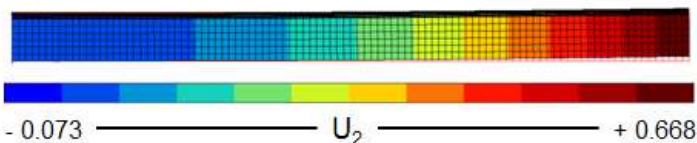

(b)

$$
\varnothing_{\text {cell }}=40 \mathrm{~mm}
$$

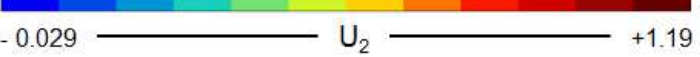

Figure 7. Scale effect on the curvature of the cell at $1100{ }^{\circ} \mathrm{C}$ for 5 hours. 


\section{Conclusion}

A thermo-mechanical model was developed in order to predict deformation during sintering of a self-supported current collector SOFC. This model was fed with mechanical and morphological parameters deduced from dilatometric and creep tests. The numerical simulations were carried out assuming that materials are homogeneous media and implementing various cell diameters and sintering temperature as these two parameters are likely to influence deformation of the multilayered structure after thermal treatment. Finite element simulations demonstrated that plane and stackable cells can be fabricated after sintering at $1100{ }^{\circ} \mathrm{C}$ for 5 hours if and only if the starting powders are identical to those ones used for dilatometric and three-point bending tests. Indeed, sinterability of a pulverulent material depends on its granulometry while creep properties are linked to the microstructure of the related dense bodies.

\section{Acknowledgments}

The research leading to these results has received funding from the European Union's Seventh Framework Programme (FP7/2007-2013) for the Fuel Cells and Hydrogen Joint Technology Initiative under grant agreement $\mathrm{N}^{\circ}$ 303429. The author thanks the CerPoTech company for supplying the powders.

\section{References}

1. F. Han, A. Leonide, T. Van Gestel, H.P. Buchkremer, in the $10^{\text {th }}$ European Fuel Cell Forum, Luzern, Switzerland (2010).

2. M. Lang, C. Westner, R. Geieregger, B. bentlohner, R. Schwub, in the $10^{\text {th }}$ European Fuel Cell Forum, Luzern, Switzerland (2010).

3. P. Lohsoontorn, D.J.L. Brett, N.P. Brandon, J. of Power Sources, 183, 232-239 (2008).

4. D.G. Ivey, E. Brightman, N. Brandon, J. of Power Sources, 195, 6301-6311 (2010).

5. L. Holzer, B. Iwanschitz, Th. Hocker, B. Münch, M. Prestat, D. Wiedenmann, U. Vogt, P. Holtappels, J. Sfeir, A. Mai, Th. Graule, J. of Power Sources, 193(3), 1279-1294 (2011).

6. S.D. Ebbesen and M. Mogensen, Electrochemical and Solid State Letters, 13, B106-B108 (2010).

7. T. Klemenso, M. Mogensen, J. Amer. Ceram. Soc., 90, 3582-3588 (2007).

8. P. Bance, N.P. Brandon, B. Girvan, P. Holbeche, S.O'Dea, B.C.H. Steele, J. Power Sources, 131, 86-90 (2004).

9. P. Szabo, J. Arnold, T. Franco, M. Gindrat, A. Refke, A. Zagst, A. Ansar, ECS Transactions, 25(2), 175-185 (2009).

10. J. Besson and R. Fœrch, Rev. Eur. Elém. Finis, 7(5), 535-566 (1998).

11. S. Sarbandi, Ph.D thesis, Mines ParisTech (2011).

12. K. Maca, V. Pouchly, A.R. Boccaccini, Science of Sintering, 40, 117-122 (2008).

13. L. Amaral, A.M.R. Senos, P.M. Vilarinho, Mater. Res. Bull., 44, 263-270 (2009). 